\title{
Determination of formalin in animal and poultry inactivated vaccines using different methods
}

\author{
N. A.Y. Sherif \\ Central Laboratory for Evaluation of Veterinary Biologics, abbasia, Cairo, Egypt
}

\begin{abstract}
In this study, two methods for determination of formalin amount were applied on samples of inactivated vaccines representing local or foreign companies. The first method; matching method was conducted by using phenyl hydrazine while in the other method is; spectrophotometry phloroglucinol was used. Spectrophotometrical method was found more sensitive and more accurate than the matching one. At the same time, the spectrophotometry method could be used for determination of formalin in all inactivated vaccines either bacterial or viral vaccines.
\end{abstract}

During vaccine production, several control tests are performed to ensure that vaccines have been made under optimal circumstances; the raw and intermediate products follow the required standard. At the end of the production process, many tests must be done on the bulk product and the final vaccine. Such tests include safety, potency, sterility, identity as well as residual chemical constituents particularly formalin which is used as inactivating agent during manufacture. Formalin is considered as toxigenic or carcinogenic material for both animals and human beings. Tests have been formulated for each vaccine according to (British Pharmacopoeia, 1973; Quality Control of Vaccine, 1983 and European Pharmacopoeia, 1997) which are generally accepted allover the world.

Brandly et al. (1946) showed that $0.025 \%$ diluted formalin could destroy the infectivity of Newcastle disease virus (NDV).

King (1991) evaluated different methods for inactivation of NDV and avian influenza viruses (AIV). He found that NDV or AIV were inactivated by binary ethyleneimine (BEI) $(0.01 \mathrm{M})$ with no adverse effect on haemagglutinating or hemolytic activities. The effect of formalin $(0.1 \%)$ was variable and depressed HI titres of antisera.

Soliman et al. (1996) found that binary ethylenimine, used as inactivating agent for NDV, had no effect on the antigenicity of the virus when used in a concentration of 0.01 or $0.03 \mathrm{M}$. These results compared favourably with those obtained when using formaldehyde solution as an inactivating agent at concentration of 0.1 or $0.2 \%$, which significantly reduced antigenicity of the haemagglutination titer of 1024 to that of 32 .
The widespread use of formaldehyde and the reports of adverse effects have created the need for specific, sensitive and simple method for its determination.

The present work aimed to compare between two currently used methods for determination of formalin; the first one is by using phenyl hydrazine and the other is by using phloroglucinol (spectrophotometry).

\section{Material and Methods}

Tested batches. Total number of (136) batches of inactivated vaccines were used in this study. These batches represent local and imported vaccines; (88) viral poultry inactivated vaccines, (29) bacterial poultry inactivated vaccines, (10) viral large animal inactivated viral vaccines and (9) inactivated bacterial vaccines of large animal.

Phenyl hydrazine method. It was carried out according to Quality Control of Vaccines (1983). Standard formaldehyde solution was prepared by measuring out $1 \mathrm{ml}$ of aqueous formaldehyde solution (40\%) into a $100 \mathrm{ml}$ standard flask and diluting to the mark with distilled water. The concentration of the solution was found to be $3800 \mathrm{ppm}$. One ppm of formaldehyde solution was prepared freshly prior to use. In five test tubes represented five concentrations $(1.0,0.50$, $0.1,0.05 \%$ and $0.01 \%$ ) of the formaldehyde (El-Gomhoria Company for Chemicals, Drugs and Medical Supplies, Egypt) standards. $1 \mathrm{ml}$ in each tube and another test tube represented the sample $(1 \mathrm{ml}$ of the tested inactivated vaccine plus $100 \mathrm{ml}$ distilled water), the following reagents were put in order: $0.1 \mathrm{ml}$ of phenyl hydrazine 1\% (Riedel-de Haen Allied Signal, Germany), $0.1 \mathrm{ml}$ of potassium ferricyanide 5\%(BDH Chemicals Ltd., Poole, England) and Three drops of concentrated hydrochloric 
Table (1): Calibration graph was drawn using the concentration (ppm) against absorbance (optical density OD).

\begin{tabular}{cc}
\hline Concentration $(\mathbf{p p m})$ & Absorbance (Optical Density) \\
\hline 0.05 & 0.1031 \\
0.10 & 0.2059 \\
0.15 & 0.3178 \\
0.20 & 0.4413 \\
0.25 & 0.6147 \\
\hline
\end{tabular}

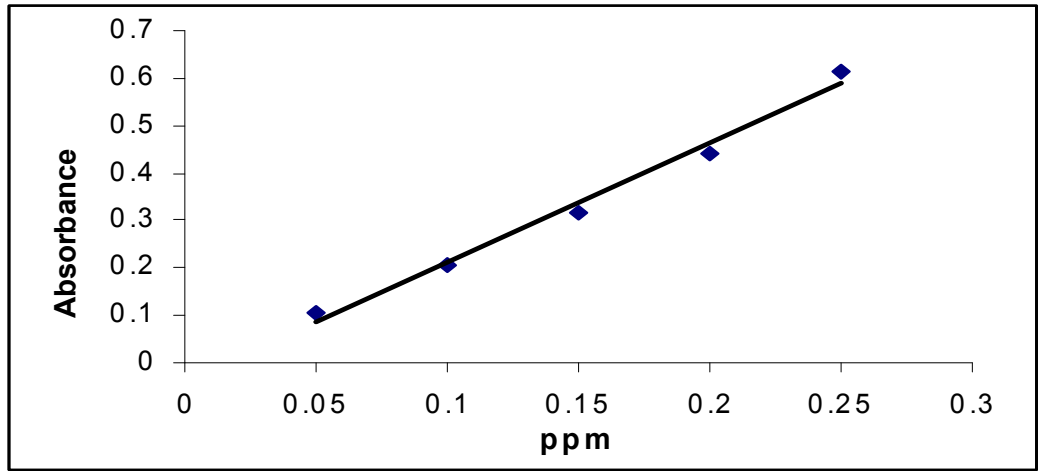

Fig. (1): Calibration graph was drawn using the concentration (ppm) against absorbance (optical density OD).

acid ( $\mathrm{HCl})$ (The Egyptian Company for Chemicals and Drugs (ADWIA), Egypt). After 5 min. the colour of both tubes was matched.

2. Phloroglucinol method. It was performed according to the method described by (Gayathri and Balasubramanian, 2000):

Preparation of Calibration Graph. In five test tubes containing $1 \mathrm{ml}$ of $1 \%$ phloroglucinal (BDH Chemicals Ltd., Poole, England), 0.5, 1.0, $1.5,2.0$ and $2.5 \mathrm{ml}$ of $1 \mathrm{ppm}$ standard formaldehyde solution was added separately. $\quad 4 \mathrm{ml}$ concentrated sulphuric acid (ADWIA Company, Egypt.) was added carefully to each tube using a long stem funnel. The solution was allowed to stand for $20 \mathrm{~min}$. to attain room temperature. The solution was then transferred into $10 \mathrm{ml}$ standard flask, washed with $1 \mathrm{ml}$ of $9 \mathrm{M}$ sulphuric acid and diluted to the mark with the same acid. Absorbance was measured at $435 \mathrm{~nm}$ against reagent blank prepared according to the same procedure (Table 1, Fig. 1).

Determination of formaldehyde in inactivated vaccines. One $\mathrm{ml}$ of the inactivated vaccine was diluted to $100 \mathrm{ml}$ with distilled water. The diluted solution was filtered and used for analysis. One $\mathrm{ml}$ of the sample solution was taken and analyzed for formaldehyde content following the procedure described under calibration graph.

Calculation. Calculation of formaldehyde concentration ( $\mathrm{ppm})$ was obtained from the calibration graph based on the following equation:

$$
\frac{\Delta \mathrm{OD}(\text { Sample })}{\Delta \mathrm{OD}(\text { Standard })} \text { X Concentration of standard }
$$

\section{Results and Discussion}

Several methods for determination of formaldehyde have been developed, e.g. high performance liquid chromatography (HPLC) method (Zegota, 1999; Sandner et al., 2001 and Possanzini and Di Pola, 2003), gas chromatography (GC) method (Ren and Guo, 1997; Suliman and Soma, 2000 and Shiraishi et al., 2001), laser spectrometer (Rehle et al., 2001 and Richter et al., 2002) and by spectrophotometry (Lodge, 1989; Lancaster et al., 2000; Ross et al., 2002 and Mason et al., 2004).

In this study, two methods were used; the principle of the first method is base on the reaction of formaldehyde with phenyl hydrazine solution $(1 \%)$, potassium ferricyanide $(5 \%)$ in acid solution $(\mathrm{HCl})$ forming a red to faint pink coloured compound, the intensity of which can be matched visually with $1,0.50,0.1,0.05$ and $0.01 \%$ of formaldehyde standard solutions (Quality Control of Vaccines, 1983). The second method is based on the reaction of formaldehyde with phloroglucinol in acidic solution (Gayathri and Balasubramanian, 2000). 
Table (2): Determination of formaldehyde concentration (\%) in random batches of inactivated vaccines using visual method (Matching).

\begin{tabular}{|c|c|c|c|c|c|c|c|c|c|c|c|}
\hline \multicolumn{6}{|c|}{ Poultry inactivated vaccines } & \multicolumn{6}{|c|}{ Large animal inactivated vaccines } \\
\hline \multicolumn{3}{|c|}{ Viral Vaccines } & \multicolumn{3}{|c|}{ Bacterial vaccines } & \multicolumn{3}{|c|}{ Viral Vaccines } & \multicolumn{3}{|c|}{ Bacterial vaccines } \\
\hline Type & $\begin{array}{l}\text { No. of } \\
\text { batches }\end{array}$ & Mean+SE & Type & $\begin{array}{c}\text { No. of } \\
\text { batches }\end{array}$ & Mean+SE & Type & $\begin{array}{c}\text { No. of } \\
\text { batches }\end{array}$ & Mean + SE & Type & $\begin{array}{l}\text { No. of } \\
\text { batches }\end{array}$ & Mean+SE \\
\hline ND & 44 & $0.044+0.002$ & Cholera & 9 & $0.049+0.007$ & RVF & 3 & $0.05+0.0$ & $\begin{array}{c}\text { Ovine \& } \\
\text { caprine HS }\end{array}$ & 2 & $0.05+0.0$ \\
\hline IBD & 8 & $0.05+0.0$ & Coryza & 10 & $0.03+0.006$ & AHS & 2 & $0.05+0.0$ & Clostridia & 3 & $0.03+0.02$ \\
\hline EDS & 5 & $0.038+0.007$ & FRHS & 6 & $1.0+0.0$ & Entero-3 & 2 & $0.01+0.0$ & Black leg & 2 & $0.05+0.0$ \\
\hline RVHS & 4 & $0.05+0.0$ & $\mathrm{MG}$ & 2 & $0.01+0.0$ & FMD & 3 & $0.01+0.0$ & Cattle HS & 2 & $0.1+0.0$ \\
\hline $\mathrm{ND}+\mathrm{TRT}$ & 2 & $0.53+0.48$ & E. coli & 2 & $0.01+0.0$ & & & & & & \\
\hline $\mathrm{ND}+\mathrm{IB}$ & 2 & $0.05+0.0$ & & & & & & & & & \\
\hline ND+IBD & 5 & $0.034+0.009$ & & & & & & & & & \\
\hline $\mathrm{ND}+\mathrm{EDS}$ & 2 & $0.1+0.0$ & & & & & & & & & \\
\hline $\mathrm{ND}+\mathrm{IB}+\mathrm{EDS}$ & 4 & $0.05+0.0$ & & & & & & & & & \\
\hline $\mathrm{ND}+\mathrm{IB}+\mathrm{SHS}$ & 2 & $0.02+0.0$ & & & & & & & & & \\
\hline $\mathrm{ND}+\mathrm{IB}+\mathrm{IBD}$ & 3 & $0.05+0.0$ & & & & & & & & & \\
\hline $\mathrm{ND}+\mathrm{IB}+\mathrm{IBD}+\mathrm{Reo}$ & 3 & $0.04+0.01$ & & & & & & & & & \\
\hline PPMV & 2 & 0.01 .0 .04 & & & & & & & & & \\
\hline $\mathrm{AE}$ & 2 & $0.025+0.015$ & & & & & & & & & \\
\hline Total & 88 & $0.12+0.03$ & & 29 & $0.24+0.07$ & & 10 & $0.039+0.007$ & & 9 & $0.057+0.009$ \\
\hline
\end{tabular}

Mean + Standard Error (SE) 
Table (3): Determination of formaldehyde concentration (\%) in random batches of inactivated vaccines using spectrophotometry method.

\begin{tabular}{|c|c|c|c|c|c|c|c|c|c|c|c|}
\hline \multicolumn{6}{|c|}{ Poultry inactivated vaccines } & \multicolumn{6}{|c|}{ Large animal inactivated vaccines } \\
\hline \multicolumn{3}{|c|}{ Viral Vaccines } & \multicolumn{3}{|c|}{ Bacterial vaccines } & \multicolumn{3}{|c|}{ Viral Vaccines } & \multicolumn{3}{|c|}{ Bacterial vaccines } \\
\hline Type & $\begin{array}{c}\text { No. of } \\
\text { batches }\end{array}$ & Mean+SE & Type & $\begin{array}{c}\text { No. of } \\
\text { batches }\end{array}$ & Mean+SE & Type & $\begin{array}{c}\text { No. of } \\
\text { batches }\end{array}$ & Mean+SE & Type & $\begin{array}{c}\text { No. of } \\
\text { batches }\end{array}$ & Mean+SE \\
\hline ND & 10 & $0.0465+0.001$ & Cholera & 5 & $0.0522+0.001$ & RVF & 3 & $0.0518+0.003$ & $\begin{array}{c}\text { Ovine \& } \\
\text { caprine HS }\end{array}$ & 2 & $0.0535 \pm 0.001$ \\
\hline IBD & 3 & $0.0521 \pm 0.002$ & Coryza & 5 & $0.0352 \pm 0.001$ & AHS & 2 & $0.0507 \pm 0.0003$ & Clostridia & 3 & $0.0311 \pm 0.003$ \\
\hline EDS & 3 & $0.0395+0.001$ & FRHS & 3 & $1.0209+0.02$ & Entero-3 & 2 & $0.0171+0.002$ & Black leg & 2 & $0.0514+0.001$ \\
\hline RVHS & 3 & $0.0532 \pm 0.001$ & $\mathrm{MG}$ & 2 & $0.0159 \pm 0.0002$ & FMD & 3 & $0.0016 \pm 0.0003$ & Cattle HS & 2 & $0.1088 \pm 0.002$ \\
\hline $\mathrm{ND} \pm \mathrm{TRT}$ & 2 & $0.0534 \pm 0.003$ & E. coli & 2 & $0.0151 \pm 0.0003$ & & & & & & \\
\hline $\mathrm{ND} \pm \mathrm{IB}$ & 2 & $0.0563 \pm 0.002$ & & & & & & & & & \\
\hline $\mathrm{ND} \pm$ IBD & 5 & $0.0323 \pm 0.001$ & & & & & & & & & \\
\hline $\mathrm{ND} \pm \mathrm{EDS}$ & 2 & $0.1058 \pm 0.001$ & & & & & & & & & \\
\hline $\mathrm{ND} \pm \mathrm{IB}+\mathrm{EDS}$ & 3 & $0.0507 \pm 0.001$ & & & & & & & & & \\
\hline $\mathrm{ND} \pm \mathrm{IB} \pm \mathrm{SHS}$ & 2 & $0.0269 \pm 0.002$ & & & & & & & & & \\
\hline $\mathrm{ND} \pm \mathrm{IB} \pm \mathrm{IBD}$ & 3 & $0.0516 \pm 0.001$ & & & & & & & & & \\
\hline $\mathrm{ND} \pm \mathrm{IB} \pm \mathrm{IB} D \pm \mathrm{Reo}$ & 3 & $0.0446 \pm 0.001$ & & & & & & & & & \\
\hline PिMV & 2 & $0.0155 \pm 0.001$ & & & & & & & & & \\
\hline $\mathrm{AE}$ & 2 & $0.0301 \pm 0.0002$ & & & & & & & & & \\
\hline Total & 45 & $0.0462+0.002$ & & 17 & $0.2095+0.09$ & & 10 & $0.0296+0.007$ & & 9 & $0.0579 \pm 0.01$ \\
\hline
\end{tabular}

Mean \pm Standard Error (SE)

Table (4): Comparison between determination of formaldehyde concentration (\%) in random batches of inactivated vaccines using visual method (Matching) and spectrophotometry method.

\begin{tabular}{|c|c|c|c|c|}
\hline \multirow{2}{*}{ Type of vaccine } & \multicolumn{2}{|c|}{ Visual method (matching) } & \multicolumn{2}{|c|}{ Spectrophotometry method } \\
\hline & No. of batches & Mean \pm SE & No. of batches & Mean \pm SE \\
\hline Viral poultry inactivated vaccines & 88 & $0.12 \pm 0.03$ & 45 & $0.0462 \pm 0.002$ \\
\hline Bacterial poultry inactivated vaccines & 29 & $0.24 \pm 0.07$ & 17 & $0.2095 \pm 0.09$ \\
\hline Viral large animal inactivated vaccines & 10 & $0.039 \pm 0.007$ & 10 & $0.0296 \pm 0.007$ \\
\hline Bacterial large animal inactivated vaccines & 9 & $0.057 \pm 0.009$ & 9 & $0.0579 \pm 0.01$ \\
\hline
\end{tabular}

Mean \pm Standard Error (SE) 
The obtained results were illustrated in (Tables 2-4) which showed determination of formaldehyde percent in 136 random batches of inactivated vaccines used in this study, which were collected during the period of (2004-2005). These batches represent local and imported vaccines including 88 viral poultry inactivated vaccines, 29 bacterial poultry inactivated vaccines, 10 viral large animal inactivated vaccines and 9 bacterial large animal inactivated vaccines.

From the obtained results, it was noted that the mean percentage of formaldehyde of the viral poultry inactivated vaccines was $(0.0462$ $\%)$ by spectrophotometrical method and $(0.12$ $\%$ ) by the visual method. On the other hand, formaldehyde mean percentages in bacterial poultry inactivated vaccines were 0.2095 and $0.24 \%$ in the spectrophotometrical and in visual methods respectively. The viral large animal inactivated vaccines show mean percentage of $0.0296 \%$ and $0.039 \%$ by spectrophotometrical and visual methods respectively. Bacterial large animal inactivated vaccines showed formaldehyde mean percentage of 0.0579 and $0.057 \%$ by spectrophotometrical and visual methods respectively.

Although the two methods gave nearly the same values, it is very clear that the spectrophotometry method is more sensitive than the visual one, where the former gave very accurate percentage of formaldehyde while the later gave approximate values. The obtained results are in agreement with those obtained by (Gayathri and Balasubramanian, 2000) who said that the determination of formaldehyde spectrophotometrically using phloroglucinal is a simple, accurate and very sensitive method, also with Ross et al. (2002) who conducted an international collaborative study of quantitative colorimetric method for determination of formaldehyde in veterinary vaccines products by 15 laboratories in North America, Europe and Japan. Moreover, Amer (2004) revealed that the developed spectrophotometry method using Rosaniline was conveniently applied to the determination of traces of formaldehyde in veterinary biological products.

In conclusion, the determination of formaldehyde spectrophotometrically using phloroglucinol method is more simple, accurate and sensitive than the visual (matching) method. The spectrophotometry method could be used for determination of formaldehyde not only in the poultry viral inactivated vaccines but also in all veterinary inactivated vaccines either bacterial or viral.

\section{Acknowledgement}

The author is deeply grateful to Prof. Dr. Mohamed M. Taha, Director of Central Laboratory for Evaluation of Veterinary Biologics, Abbasia, Cairo, Egypt for his kind and great help.

\section{References}

Brandly, C. A.; Moses, M. E.; Jones, E. E. and Jungherr, E. L. (1946): Immunization of chickens against ND. Amer. J. Vet. Res., 7: 307-332.

British Pharmacopoeia (1973): London Her Majesty's Stationery Office.

European Pharmacopoeia (1997): $3^{\text {rd }}$ ed. Published in accordance with the convention on the Elaboration of a European Pharmacopoeia. Council of Europe, Strasbourg.

Gayathri, N. and Balasubramanian, N. (2000): Spectrophotometric determination of formaldehyde. Analyt. Lett., 33 (14): 3037-3050.

King, D. J. (1991): Evaluation of different methods of inactivation of NDV in egg fluid and serum. Avian Dis., 35 (35): 505

Lancaster, D. G.; Fried, A.; Wert, B.; Henry, B. and Tittel, F. K. (2000): Difference-frequency-based tunable absorption spectrometer for detection of atmospheric formaldehyde. Appl. Opt., 39 (24): 4436-4443.

Lodge, J. P. (1989): Methods of air sampling and analysis. $3^{\text {rd }}$ ed. Lewis Publishers, Michigan, pp. 274-278.

Mason, D. J.; Sykes, M. D.; Panton, S. W. and Rippon, E. H. (2004): Determination of naturally occurring formaldehyde in raw and cooked mushrooms by spectrophotometry. Food Addit. Contam., 21 (11): 10711082.

Amer, N. A. A. (2004): Determination of quantity of some additives in veterinary biologics. Fac. Sci., Ain Shams Univ., Egypt.

Possanizi, M. and Di Pola, V. (2003): Simultaneous determination of formaldehyde in ambient air by hydrazine reagent and HPLC. Ann. Chim., 93 (1-2): 149-156.

Quality Control of Vaccines (1983): Rijksinstituut Voor Volksgezondheid En Milieuhygiene Bilthoven, The Netherlands. Egypt. Org. Biol. Prod. Vaccines Library, Agouza, Giza, Egypt.

Rehle, D.; Leleux, D.; Erdelyi, M.; Tittel, F.; Fraser, M. and Friedfeld, S. (2001): Ambient formaldehyde detection with a laser spectrometer based on difference frequency generation in PPLN. Appl. Phys. B; 72 (8): 947.

Ren, Q. and Guo, Y.J. (1997): Rapid determination of low molecular weight aldehydes in air by gas chromatography. Se Pu., 15 (4): 356-357.

Richter, D.; Fried, A.; Wert, B. P.; Walega, J. G. and Tittel, F. K. (2002): Development of a tunable mid-IR difference frequency laser source for highly sensitive airborne trace gas detection. Appl. Phys. B; 75 (2-3): 281-288.

Ross, P. F.; Draayer, H. and Itoh, O. (2002): In international collaborative study on a method for determination of formaldehyde in veterinary vaccines. Biologicals, 30 (1): 37-41.

Sandner, F.; Dott, W. and Hollender, J. (2001): Sensitive indoor air monitoring of formaldehyde and other carbonyl compounds using the 2,4-dinitrophenyl hydrazine method. Int. J. Hyg. Environ. Health, 203 (3): 275-279.

Shiraishi, T.; Soma, Y.; Ishitani, O. and Sakamoto, K. (2001): Application of an integrated prepstation-GC-NPD 
system to automated continous measurement of formaldehyde and acetaldehyde in the atmosphere. J. Environ. Monit; 3 (6): 654-660.

Soliman, S. M.; Hamdy, A.; Zaghloul, W. A. and ElBordiny, F. (1996): Assiut Vet. Med. J., 35 (69): 157.

Suliman, F. E. and Soma, Y. (2000): The determination of carbonyl compounds in air using a robotic sampling preparation system integrated to a gas chromatograph with a nitrogen-phosphorus detector. J. Env. Monit, 2 (5): 470-475.

Zegota, H. (1999): High-performance liquid chromatography of methanol released from pectins after its oxidation to formaldehyde and condensation with 2,4-dinitrophenyl hydrazine. J. Chromat. A., 863 (2): 227-233. 